Primljen / Received: 29.10.2015. Ispravljen / Corrected: 20.9.2017.

Prihvaćen / Accepted: 2.7.2018.

Dostupno online / Available online: 25.10.2018.

\section{Application of geological strength index for characterization of weathering-induced failures}

Authors:

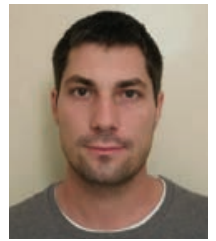

Zoran Berisavljević, PhD Eng. Geol.

Koridori Srbije Ltd.

z.berisavljevic@koridorisrbije.rs

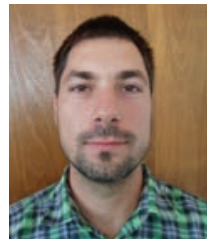

Dušan Berisavljević, PhD Eng. Geol.

Institute for Materials Testing

dusan.berisavljevic@institutims.rs

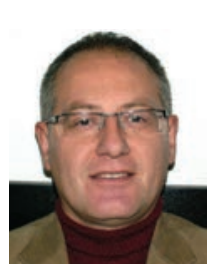

Prof. Dragoslav Rakić, PhD Eng. Geol.

University of Belgrade

Faculty of Mining and Geology

dragoslav.rakic@rgf.bg.ac.rs

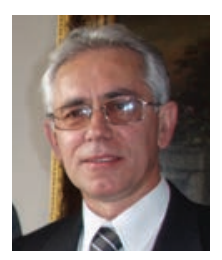

Assist.Prof. Zoran Radić, PhD Eng. Geol.

University of Belgrade

Faculty of Civil Engineering

zoradic@grf.bg.ac.rs

\section{Zoran Berisavljević, Dušan Berisavljević, Dragoslav Rakić, Zoran Radić}

Professional paper

\section{Application of geological strength index for characterization of weathering- induced failures}

This study investigates weathering induced failures of the heterogeneous fissile rock mass consisting of sandstone and shale. Discontinuity data was collected and the geological strength index (GSI) value was determined immediately after excavation based on the quantified GSI chart. Slake durability tests were performed up to the fifth cycle. Samples were exposed to natural climatic conditions during a twelvemonth period, in order to quantify slaking process by means of disintegration ratio. As a consequence of exposure, samples disintegrated into smaller fragments. On these bases, the model aimed at addressing delayed failure of cuts is proposed in the paper.

Key words:

slaking, heterogeneity, fissility, disintegration ratio, GSI reduction

Stručni rad

Zoran Berisavljević, Dušan Berisavljević, Dragoslav Rakić, Zoran Radić

Primjena geološkog indeksa čvrstoće za opis rastrošbom izazvanih slomova

U radu se istražuje rastrošbom izazvani slom heterogene lisnate stijenske mase koja se sastoji od pješčenjaka i šejla. Prikupljeni su podaci o diskontinuitetima, a vrijednost geološkog indeksa čvrstoće (GSI) utvrđena je odmah nakon iskopa na temelju kvantificiranog GSI dijagrama. Ispitivanja trajnosti izvedena su do petog ciklusa. Uzorci su bili izloženi prirodnim klimatskim uvjetima tijekom 12-mjesečnog razdoblja kako bi se kvantificirao proces kalanja pomoću indeksa trajnosti. Posljedica izloženosti uzoraka je bila dezintegracija u manje fragmente. Na ovim osnovama predložen je model za rješavanje zakašnjelog sloma usjeka.

Ključne riječi:

kalanje, heterogenost, lisnatost, indeks trajnosti, smanjenje GSI

Fachbericht

Zoran Berisavljević, Dušan Berisavljević, Dragoslav Rakić, Zoran Radić

Anwendung des geologischen Festigkeitsindex für die Beschreibung von durch Verwitterung hervorgerufene Brüche

In der Abhandlung untersucht man durch Verwitterung hervorgerufene Brüche bei heterogenen blättrigen Felsenmassen, die aus Sandstein und Tonschiefer bestehen. Zusammengetragen wurden Daten über die Diskontinuität, und die Werte des geologischen Festigkeitsindex (GSI) wurden sofort nach dem Aushub aufgrund des quantifizierten GSI-Diagramms festgestellt. Die Untersuchungen der Beständigkeit wurden bis zum fünften Zyklus durchgeführt. Außerdem waren die Proben während eines 12-monatigen Zeitraums den natürlichen klimatischen Bedingungen ausgesetzt, um den Spaltungsprozess mithilfe des Beständigkeitsindex zu quantifizieren. Die Folge der Exposition der Proben war die Desintegration in kleinere Fragmente. Auf diesen Grundlagen wurde ein Modell für die Lösung des verspäteten Bruchs des Einschnitts vorgeschlagen.

Schlüsselwörter:

Spaltung, Heterogenität, Blätterung, Beständigkeitsindex, Verringerung des GSI 


\section{Introduction}

When dealing with cuttings constructed in clay bearing rock, the risk of delayed failures is present due to possible degradation over time. These failures, although usually shallow in nature, have negative consequences such as the extension of project deadlines, increase in repair and maintenance costs, contractor's claim requests, and loss of stability of facilities at the toe and crest of the slope. The cause of such instabilities is attributed to weathering processes that occur immediately after excavation. Natural climatic conditions cause changes in moisture content, temperature and physical conditions of free water in the rock mass. This leads to mechanical and chemical weathering of the material. Weathering of rock mass decreases its shear strength and increases deformability. Specific type of weathering, when wetting and drying cycles are involved, is termed slaking. The slaking is characteristic for fine grained rock masses (mudstone, clay shale, marlstone, siltstone, claystone). Softening by means of slaking is closely related to strain softening i.e. progressive failure. Bjerrum [1] defines two phases during weathering of overconsolidated plastic clays and clay shales. In the first phase, the structure of clay is disturbed by the breakdown of bonds between clay particles, whereas in the second phase chemical processes cause decomposition of minerals. The first disintegration phase starts and ends relatively fast after exposure to weathering agents, and has a major influence on mechanical properties of the rock mass. The major agent in the destruction of diagenetic bonds is strain. Many physical processes can produce strain, and their influence decreases with depth. Botts [2] quotes a strength reduction of clay shales between 40 and $80 \%$ with angle of shear resistance reduced from initial $20^{\circ}-30^{\circ}$ to $6^{\circ}-8^{\circ}$ after disintegration. By testing clay shales in triaxial apparatus, $80 \%$ strength reduction was obtained after one cycle of wetting and drying. The strength reduction of $90 \%$ was obtained after testing on argilites [3]. Miščević and Vlastelica [4] emphasize that if cut slopes in flysch rock mass stay unprotected, the failures could develop within months after excavation. The influence of laboratory simulated weathering on the shear strength of marl was also studied [5]. Lithological factors such as the degree of cementation, existence of microcracks, grain size, heterogeneity, and mineralogical composition (type of clay minerals), have an influence on disintegration. Materials with higher plasticity limit, porosity, and moisture content, are more susceptible to slaking. Different opinions exist among authors on the causes of slaking of clay bearing rocks. Several authors $[6,7]$ advocate hypothesis of the existence of complex physical and chemical reactions between molecules of water that exist in the rock mass pores. Infiltration of atmospheric water with the chemistry different from that within the rock mass can weaken intermolecular bonds between particles, leading to disintegration of the rock mass. Others $[8,9]$ assume that the disintegration process is closely related to suction effects. After drying, air fills pores and high suction pressures start to develop. In the case of subsequent water infiltration, the pressure around trapped air bubbles increases, producing additional pressures on mineral grains within the rock mass. After several wetting and drying cycles, high pressures can lead to fragmentation of the rock mass. In the case of active clays prone to swelling, the destruction of diagenetic bonds starts when the rock mass tensile strength is exceeded by swelling pressure. In the case of fissile rock mass, slaking could be more pronounced than in the case of their massive equivalents. Botts [2] quotes that fissures control behaviour of the rock mass threefold, and presents the model for clay shale disintegration. The failure of soft rock material can occur at any stage of deterioration, and requires only reduction of shear strength to a level such that it can no longer resist shear stresses acting on the potential slip surface.

Some of the properties that should be investigated to determine whether rock mass is prone to slaking are the adsorption, liquid limit, plasticity limit, presence of clay minerals, swelling potential, etc. It is desirable to determine these properties during the design process in order to reliably determine rock mass behaviour after excavation. Several authors [10-12] suggested classifications to assess durability of clay bearing rocks.

Weathering and slaking effects were studied during construction of cut slopes on the E80 Highway Project in Serbia.
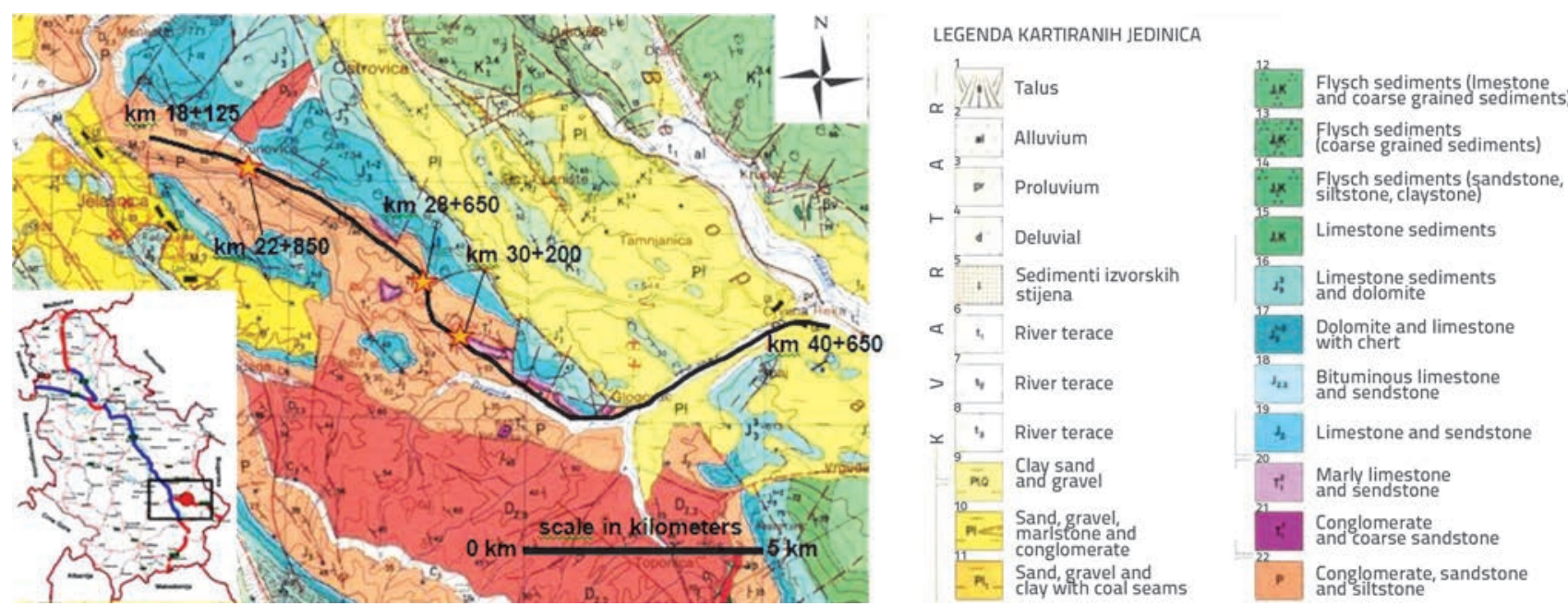

Figure 1. Geological map of Serbia [15]; black solid line represents first section of E80 Highway Project crossing Permian deposits 


\section{Geological setting}

Instabilities caused by weathering processes can be observed on cut slopes excavated during construction of the E80 Highway Project in Serbia, from chainage 22+000 to chainage 34+000. After excavation of the majority of cuts, from 10 to over $35 \mathrm{~m}$ in height, more than 10 instabilities were registered over a period of one year. All cuttings are formed with $v: h=1: 1$ inclination (locally $1: 1.5$ ), without surface vegetative or shotcrete cover. The geology of this part of alignment is mainly characterized by Permian heterogeneous rock masses represented by sandstone, siltstone, and mudstone interchanging in different proportions, Figure 1. Permian deposits are widely spread in southern and central parts of Serbia, and are characterized as braided river deposits [13], i.e. deposits formed in the fluvial depositional environment. More details on mineralogical and geological characteristics are given by Berisavljevic [14]. According to classification by Potter-a et al. [16] the rock is characterized as mud shale to silty shale.

\section{Failures induced by weathering}

Typical failures induced by weathering are shown in Figure 2. Cuttings remained stable during the first several months after exposure. First signs of instabilities occurred when cracks parallel to the slope face developed at different heights along the slope, usually in the toe or at mid-height of the slope. Progression of cracks and deterioration of rock mass was monitored until the failure in three locations namely, at km 22+850, km

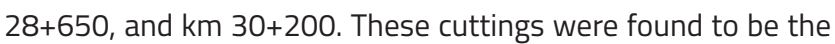
most representative for studying weathering process. Table 1 shows data collected during site investigations conducted for the construction and remediation of cuttings. Inclinometers showed displacements in the order of only several millimetres prior to failure, and no sign of displacements acceleration. Thus, they were of limited use for predicting failures. However, they can be used for determining exact position of sliding surface. In all measured stand pipe piezometers, the ground water level remained well below ground surface during the monitoring period of one year. Maximum water level variation after heavy rainfalls is $2 \mathrm{~m}$. Sliding surfaces are shallow in nature, and exhibit $4 \mathrm{~m}$ in maximum thickness. They are formed above the zone of influence of phreatic surface.

\subsection{Failure at KM $30+200$}

Excavation of cuttings between chainages $30+000$ and 30+350 started in April 2013 and final geometry was obtained in October 2013. First cracks appeared on the slope face in late November and early December 2013, Figure 3.a. At the beginning of February 2014, the instability extended to the lower portion of the slope, Figure 3.b. By the end of September 2014, first cracks developed at the crest of the slope, and sliding surface was formed by November 2014, Figure 3.c. Further lateral progression of landslide is shown in Figure 2. Overall movements are not large and failed material serves as protective cover, which slows down disintegration of deeper layers.
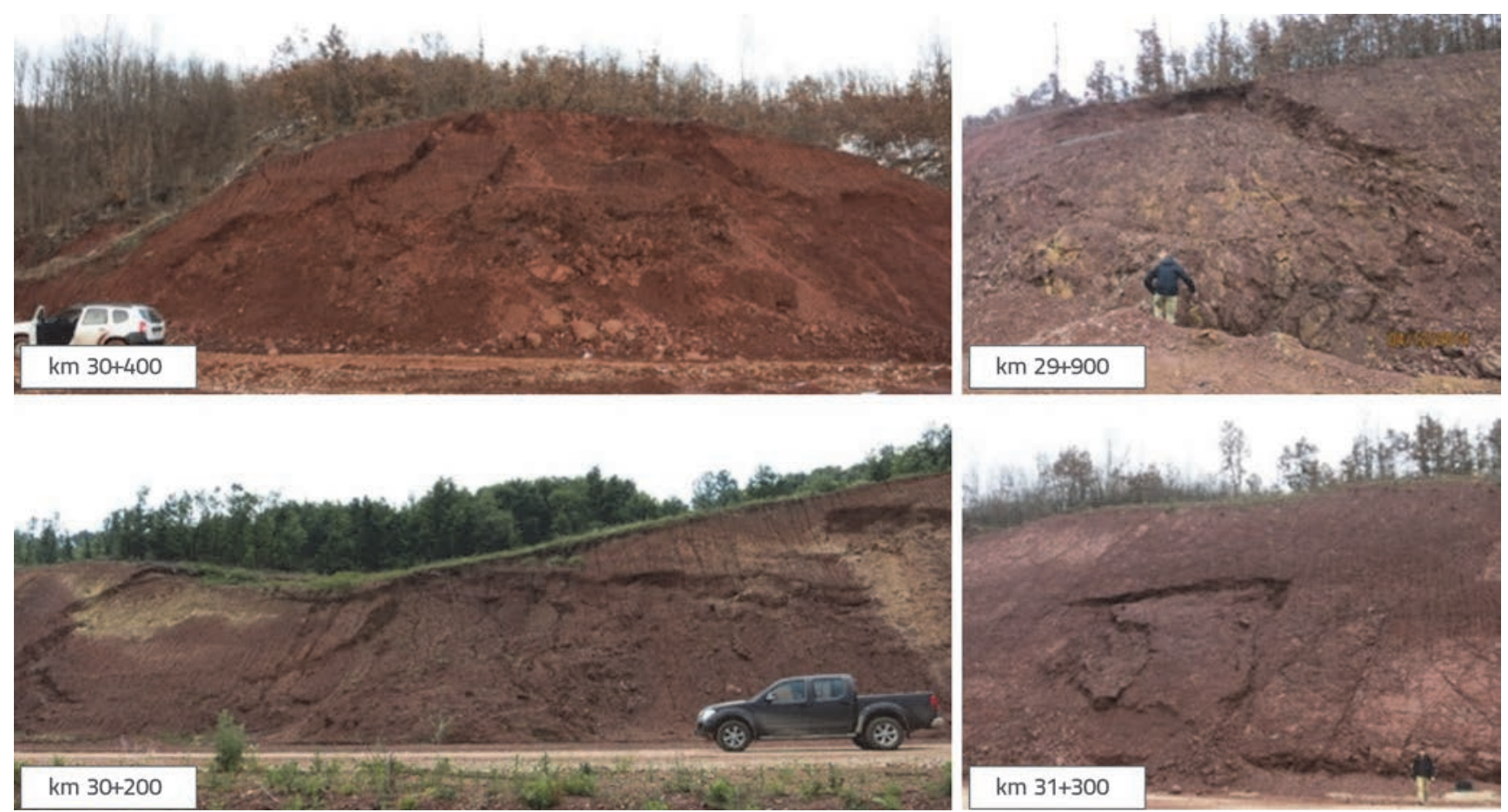

Figure 2. Typical failures in Permian shales and mudstones 
Table 1. Available site investigation and monitoring data

\begin{tabular}{|c|c|c|c|c|}
\hline Approx. cutting chainage & $\begin{array}{l}\text { Slope geometry } \\
(v: h) \text { and height }\end{array}$ & $\begin{array}{c}\text { Geotechnical data } \\
\text { available }\end{array}$ & $\begin{array}{l}\text { Time to failure after excavation } \\
\text { and estimated or measured } \\
\text { thickness of sliding surface }\end{array}$ & $\begin{array}{l}\text { Max inclinometer disp. } \\
\text { and ground water level } \\
\text { from piezometers - qw/ }\end{array}$ \\
\hline $\mathrm{km} \mathrm{22+050}$ & $\begin{array}{c}1: 1.5 \\
h=10 \mathrm{~m}\end{array}$ & / & $\begin{array}{l}12 \text { months } \\
2.5 \mathrm{~m}\end{array}$ & $\begin{array}{l}\text { spring-constant water } \\
\text { inflow }\end{array}$ \\
\hline $\mathrm{km} \mathrm{22+850}$ & $\begin{array}{c}1: 1 \\
\mathrm{~h}=23 \mathrm{~m}\end{array}$ & $\begin{array}{c}1 \text { piezometer, } 1 \text { borehole, } \\
2 \text { PLT }\end{array}$ & $\begin{array}{l}3 \text { months } \\
3.5 \mathrm{~m}\end{array}$ & gwl $5 \mathrm{~m}$ \\
\hline $\mathrm{km} \mathrm{28+650}$ & $\begin{array}{c}1: 1 \\
\text { (upper part } 1: 2 \text { ) } \\
\mathrm{h}=35 \mathrm{~m}\end{array}$ & $\begin{array}{l}1 \text { inclinometer, } 3 \\
\text { piezometers } \\
1 \text { UCS pokusa , } 7 \text { PLT }\end{array}$ & $\begin{array}{l}6 \text { months } \\
4 \mathrm{~m}\end{array}$ & $\begin{array}{l}\text { no displ. } \\
\text { gwl } 12 \text { m }\end{array}$ \\
\hline $\begin{array}{l}\text { km 29+400 } \\
\text { entire slope (shotcreted) } \\
\text { local berm unprotected }\end{array}$ & $\begin{array}{c}\text { (2:1 toe) } 1: 1 \\
h=35 \mathrm{~m} \\
1: 1 \\
h=12 \mathrm{~m}\end{array}$ & $\begin{array}{c}4 \text { inclinometers, } 1 \\
\text { piezometer, } \\
20 \text { UCS tests }{ }^{a}, 17 \text { PLT }\end{array}$ & $\begin{array}{l}36 \text { months } \\
7 \mathrm{~m} \\
12 \text { months } \\
3 \mathrm{~m}\end{array}$ & $\begin{array}{c}\text { displacement } 15 \text { mm } \\
\text { (three pipes broken) } \\
\text { no gwl }\end{array}$ \\
\hline km 29+900 & $\begin{array}{c}1: 1 \\
h=12 \mathrm{~m}\end{array}$ & / & $\begin{array}{l}13 \text { months } \\
3 \mathrm{~m}\end{array}$ & / \\
\hline $\mathrm{km} \mathrm{30+050}$ & $\begin{array}{c}1: 1 \\
h=12 \mathrm{~m}\end{array}$ & / & $\begin{array}{l}15 \text { months } \\
3 \mathrm{~m}\end{array}$ & gwl $11 \mathrm{~m}$ \\
\hline $\mathrm{km} \mathrm{30+200}$ & $\begin{array}{c}1: 1 \\
h=12 \mathrm{~m}\end{array}$ & $\begin{array}{c}1 \text { inclinometer, } 1 \text { borehole, } \\
4 \text { UCS tests, } 4 \text { PLT }\end{array}$ & $\begin{array}{l}12 \text { months } \\
2.5 \mathrm{~m}\end{array}$ & $\begin{array}{l}\text { displacement 3-4 mm } \\
\text { gwl } 11 \mathrm{~m}\end{array}$ \\
\hline $\mathrm{km} \mathrm{30+400}$ & $\begin{array}{c}1: 1 \\
\mathrm{~h}=11 \mathrm{~m}\end{array}$ & $\begin{array}{l}2 \text { piezometers, } 2 \text { UCS } \\
\text { tests, } 10 \text { PLT }\end{array}$ & $\begin{array}{l}13 \text { months } \\
3 \mathrm{~m}\end{array}$ & / \\
\hline $\mathrm{km} \mathrm{31+000}$ & $\begin{array}{c}1: 1.5 \\
h=15 m\end{array}$ & $\begin{array}{c}1 \text { inclinometer, } 4 \text { UCS } \\
\text { tests, } 2 \text { PLT }\end{array}$ & $\begin{array}{l}15 \text { months } \\
3 \mathrm{~m}\end{array}$ & no displacement \\
\hline $\mathrm{km} \mathrm{31+300}$ & $\begin{array}{c}1: 1 \\
h=15 \mathrm{~m}\end{array}$ & / & $\begin{array}{l}\text { after } 18 \text { months just local } \\
\text { failures on slope face }\end{array}$ & / \\
\hline \multicolumn{5}{|c|}{$\begin{array}{l}\text { Note : } \\
\text { Depth to ground water level represents an average depth from all piezometers in one location during measurement period of one year; some inclinometers did not } \\
\text { show displacements as they are behind the sliding surface. UCS - uniaxial compressive strength test, PLT - point load test. aTest results also include samples from } \\
\text { adjacent cuttings (or for tunnel construction) that have not suffered from instabilities. After first failures cutting at km } 29+400 \text { (tunnel exit portal), h = } 35 \mathrm{~m} \text {, was re- } \\
\text { shaped and reinforced with } 10 \mathrm{~cm} \text { thick shotcrete and passive anchors 5-10 m in length. Failure is not only due to weathering (shown here just for reference) }\end{array}$} \\
\hline
\end{tabular}
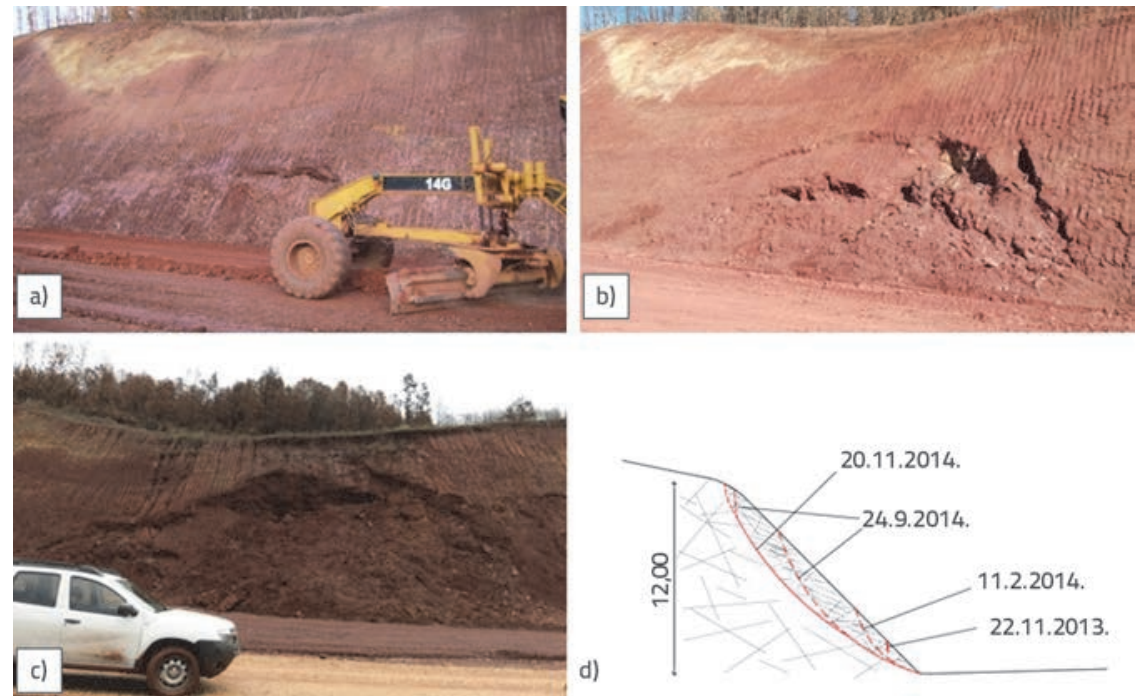

Figure 3. Failure at KM 30+200; a) 22.11.2013; b) 11.02.2014; c) 20.11.2014; d) Model of failure progression

\subsection{Failure at $\mathrm{km} 28+650$}

Construction of the left side slope of the Bancarevo Tunnel west portal ended in October 2013. It was planned to backfill $100 \mathrm{~m}$ long slope up to a certain height following construction of tunnel tubes by the cut and cover method. Previous failures at the east portal slope influenced the final slope geometry. The lower part of the cutting consists of a $4 \mathrm{~m}$ wide berm with the sope inclination of $1: 1$, while the upper part is inclined to $v: h=1: 2$. The first failure was initiated in late November 2013 at the lower portion of the slope just above the berm, Figure 4a. Progression of the failure is shown in Figures 4.b and 4.c. No further extension of failure was noted during the site visit in June 2015. This 

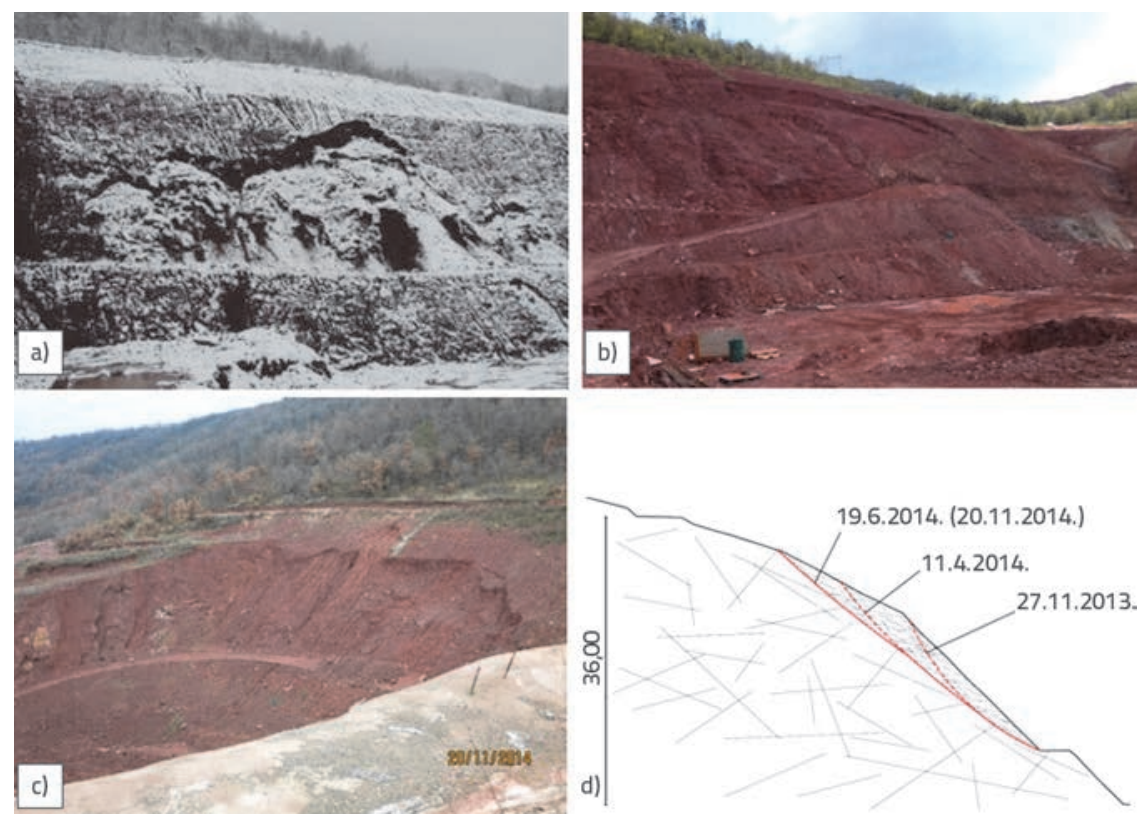

Figure 4. Failure at KM 28+650: a) 27.11.2013; b) 11.04.2014; c) 20.11.2014; d) Model of failure progression

is probably due to placement of backfill in the toe of the slope, which prevented further deterioration of the rock mass.

\subsection{Failure at $\mathrm{km} 22+850$}

The cutting was constructed with designed slope inclination of $1: 1$ in October 2013. Maximum slope height was $25 \mathrm{~m}$. First signs of instability occurred during November 2013, Figure, 5.a. In early January 2014 the crack was formed in the upper part of the slope with a trace that could be followed up to the mid-height of the slope, Figure 5.b. In mid-January the sliding surface was formed, Figure 5.c. No signs of further deterioration of the rock mass were observed until the beginning of remedial works in August 2014.

It is interesting to note that the first signs of instabilities at the studied cuttings occurred during the first month after construction. After detailed examination of all instabilities (as shown Table 1) it was noted that the failure could have been initiated at the toe of the slope where concentration of stresses is the highest, but cracks could have also been formed at mid-height of the slope. Due to this reason, it was not possible to establish the unique model of failure progression, which is probably closely related to the local heterogeneity of material at the slope face. Global failure surfaces in the first, second and third case were formed after twelve, six and three months, respectively. Time to failure is closely related to the initial quality of the rock mass and geometry of the cutting (height and inclination). Failures at km $22+850$ and $30+200$ have circular failure surfaces, while failure at $\mathrm{km} \mathrm{28+650} \mathrm{is} \mathrm{not} \mathrm{exactly} \mathrm{circular,} \mathrm{which} \mathrm{is} \mathrm{probably} \mathrm{due} \mathrm{to}$ subsequent backfilling of the cutting's toe. The failed material ranges from approx. 3.5 to $4 \mathrm{~m}$ in thickness.

\section{Initial shear strength properties of heterogeneous Permian sediments}

Determination of shear strength properties of heterogeneous rock masses is associated with many practical difficulties. This complexity arises from the fact that heterogeneous rock masses, such as Permian braided river deposits, are represented by soft (pelitic) and hard (usually sandstone) layers interchanging in different proportions. The GSI classification $[17,18]$ is a very useful tool for characterization of rock mass, and is known as the Hoek-Brown material. In its existing form, the GSI classification scheme leads to rough estimates of the GSI values. Hence, several authors [19-22] proposed quantified charts by introducing easily measurable parameters for blockiness and surface conditions of discontinuities. In this paper a combination of proposals given by Sonmez and Ulusay [19] and Cai et al. [20] is used. The total ratings 

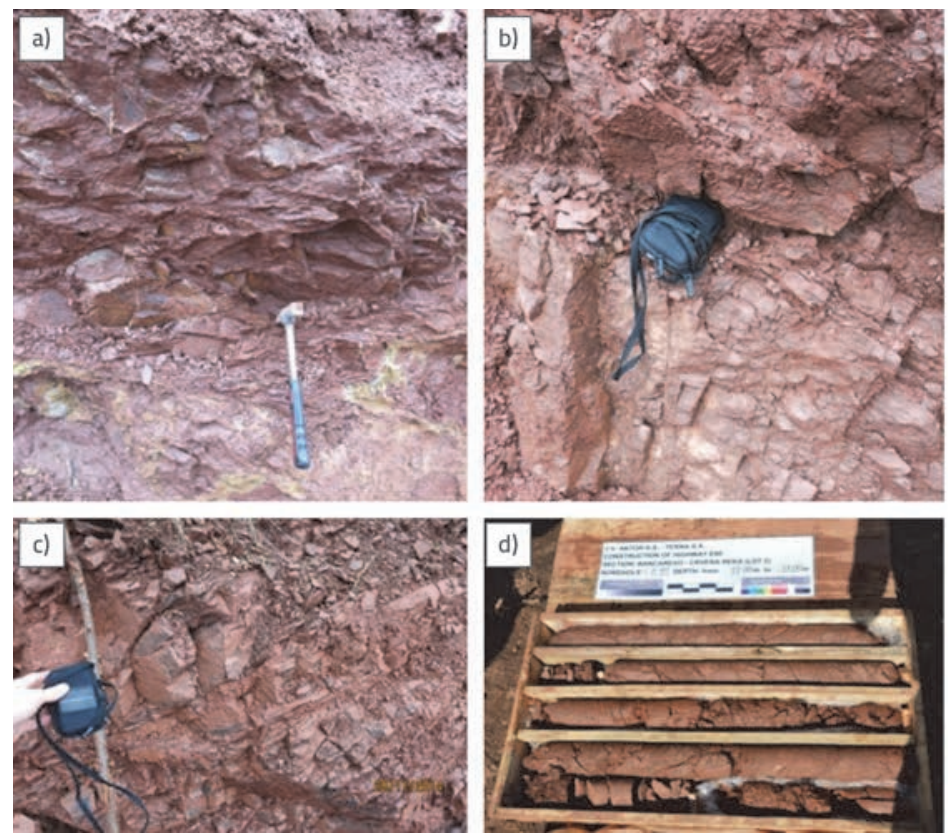
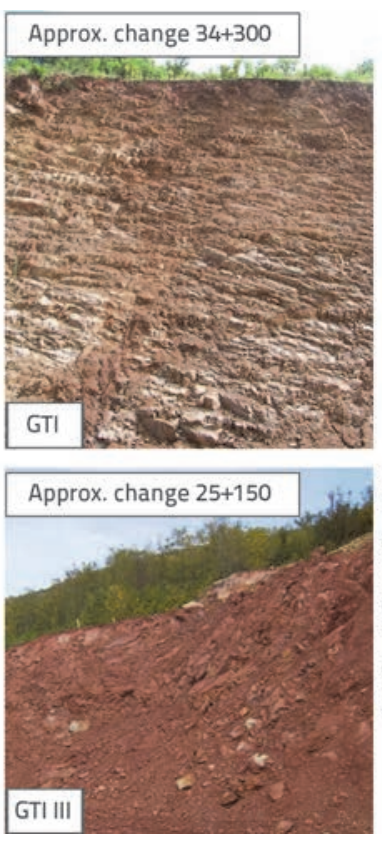

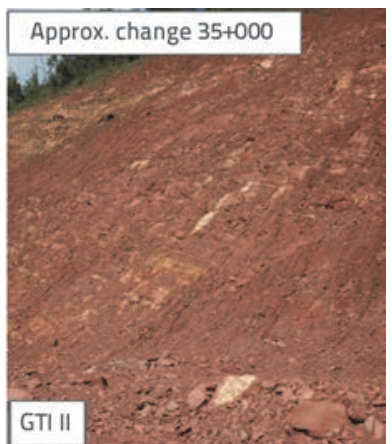

GT $(40<\mathrm{GSI}<50)$ - Cutting sandstone with thin interlayers of shale, sl-st (1:5)

GT II $(35<$ GSI $<40)$ - Sandstone and shale in similar amount, sl-st $(1: 1)$. In the case of unfavourable discontinuity orientation in unfavourable discontinuity orientation in GTI and GT II type structural instabilities
are possible and GSI is meaningless.

GT III $(30<\mathrm{GSI}<35)$ - Modarately disturbed shale with broken sandstone layers, sl-st (3:1 to 5:1)

Figure 6. Unweathered rock mass in the main scarp of landslides: a) km 30+200; b) 28+650; c) 26+300; d) core recovered from borehole at km $30+200$ and typical Permian representatives (to the right)

Table 2. Range of values for uniaxial compressive strength and surface conditions

\begin{tabular}{|c|c|c|c|c|c|}
\hline \multicolumn{6}{|c|}{ Surface conditions of discontinuities and intact rock properties } \\
\hline Lithological type & $\sigma_{\mathrm{ci}}[\mathrm{MPa}]$ & Bulk density $\left[\mathrm{kN} / \mathrm{m}^{3}\right]$ & Roughness & Weathering & Infilling \\
\hline Sandstone & $20-45^{\mathrm{a}}$ & $25.54-26.54$ & $2-4$ & $3-6$ & 4-6 \\
\hline Shale & $1-15$ & $22.59-26.53$ & $1-3$ & $2-5$ & $2-6$ \\
\hline
\end{tabular}

for surface condition are obtained by using the SCR parameter, which is calculated as a sum of ratings for roughness, weathering and infilling from RMR system [23]. The SCR parameter has been chosen as the authors are more familiar with the RMR system. The values of ratings for weathering and roughness are calculated according to Bieniawski [24], while the thickness and the type of gouge was assessed by direct inspection of joints. The rock structure is determined by assessing the block size, i.e. the volume, which is determined from the joint spacing, joint orientation, number of joint sets, and joint persistence [20]. The size of individual blocks was measured directly on site.

It is important to emphasize that rock mass classifications are related to peak (initial) shear strength properties and that their usage is justified immediately after excavation. Rock classification systems do not consider time dependent effects such as progressive failure and weathering. These effects lead to rock mass softening, shear strength reduction and, ultimately, to failure. Therefore, it is important to consider these effects for assessing the long term slope stability.

Sandstone has blocky structure, whereas shale structure is very blocky to disturbed, with blocks formed by four and more discontinuity sets, Figure 6 . Block shapes are prismatic to rhombohedral and block volume varies from several tens of cubic centimetres to several cubic decimetres [25]. Shales are typical Hoek-Brown material. Propositions for flysch were used to determine geotechnical parameters of heterogeneous rock masses $[26,27]$. Depending on the sandstone/siltstone ratio and joint surface conditions, three rock mass types (GT I-GT III) and GSI ranges were determined, Figure 6.

Table 2 shows results of laboratory testing on intact samples and data collected for determination of surface quality conditions. Characteristics of rock discontinuities were determined either on unweathered surfaces immediately after excavation, or after inspection of scarps of newly formed instabilities. It was very important to collect structural data on fresh excavated surfaces in order to avoid negative influence of weathering.

The intact uniaxial compressive strength $\sigma_{c i}$ was determined for 25 laboratory prepared cylindrical samples (10 sandstone and 15 shale samples) according to the International Society for Rock Mechanics procedure [28]. The Hoek-Brown constant $m_{i}$ was determined according to suggestions by Marinos and Hoek [26]. The values of 17 and 7 have been adopted for sandstone and shale, respectively.

Table 3 shows values of initial geotechnical properties of Permian rock mass. Figure 7 shows quantified GSI chart to account for surface quality and block size. 
Table 3. Initial geotechnical properties of Permian rock mass

\begin{tabular}{|c|c|c|c|}
\hline \multirow{2}{*}{ Geotechnical type } & \multicolumn{3}{|c|}{ Rock mass and intact properties } \\
\cline { 2 - 4 } & GSI & $\sigma_{\text {ciavg }}[\mathrm{MPa}]$ & $\mathbf{m}_{\mathbf{i}}$ \\
\hline GTI & $40-50$ & 30 & 17 \\
\hline GT II & $35-40$ & 18 & 11 \\
\hline GT III & $30-35$ & $10.5-11.25$ & $7.5-7.8$ \\
\hline ŠEJL & & 9 & 7 \\
\hline
\end{tabular}

\section{GS}

(modified after Cai et. al., 2004)

$S C R=R_{t}+R_{w}+R_{t}$

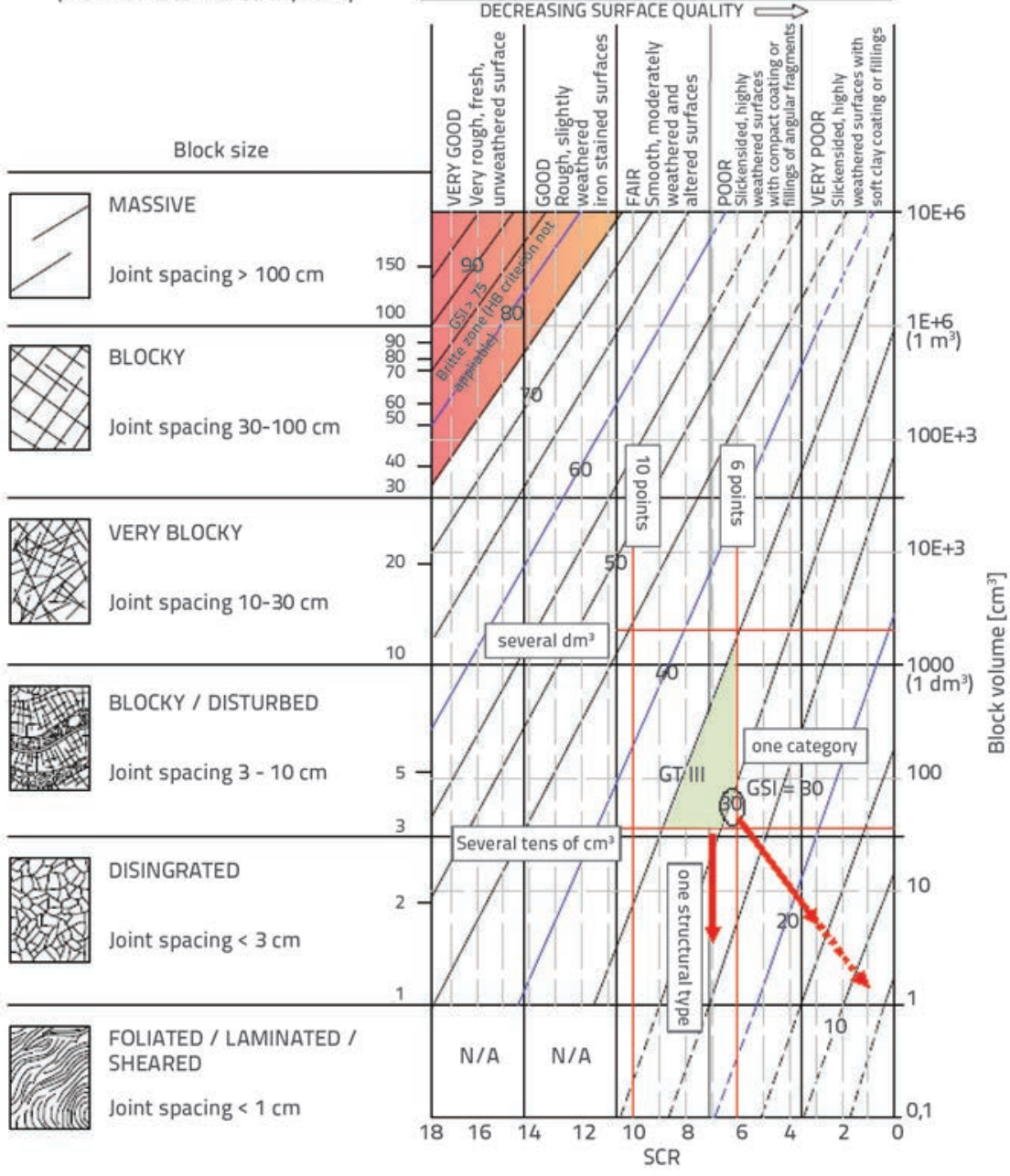

Figure 7. Quantified general GSI chart (modified after Cai et al. [20])

\section{Methodology for determination of resistance to disintegration}

Resistance to disintegration of pelitic rock masses is usually determined by laboratory tests. The engineering practice recognizes several tests such as the jar slake test [29], slake index test [30], and slake durability test [31]. Slake durability test is the most widely used and is standardized by ASTM standard [32] and recommended by the International Society for Rock Mechanics.
Several authors [33-38] suggest that more than two standardized wetting and drying cycles, usually between three and five cycles, can be performed for rocks of higher durability. Bryson et al. [39] introduced LSI (Loss Slake Index) to account for the influence of different duration of weathering cycles on the durability of shales after only one wetting and drying cycle. It is very difficult to compare results obtained under laboratory conditions with the slaking behaviour under field conditions because the in situ slaking behaviour is influenced by factors such as freezing and thawing, and variation in temperature, which cannot easily be simulated under laboratory conditions [40]. Several authors [41, 42] proposed modifications of durability tests in order to better address shale disintegration in natural conditions. In order to quantify the degree of disintegration Erguler and Shakoor [43] proposed the disintegration ratio $D_{R^{\prime}}$ calculated based on the grain size distribution curve. Gautam and Shakoor [40] used disintegration ratio to quantify the degree of disintegration after rock exposure to natural climatic conditions during a particular period of time. Samples were prepared according to ASTM D 4644 and kept in specially treated metal pans with $2.5 \mathrm{~cm}$ hole at the bottom. The hole was covered with wire mesh $1 \mathrm{~mm}$ in aperture size. This enabled drainage of atmospheric water while keeping fractions over $1 \mathrm{~mm}$ in size in the pan. Pans were laid on wooden pallets in order to remain above snow cover at all times. Limitations of artificial laboratory conditions are eliminated by this procedure. $D_{R}$ is defined as the ratio of the area under the grain size distribution curve of a given sample to the total area encompassing grain size distribution curves of all samples tested. Gautam and Shakoor [44] correlated results of laboratory tests and field experiments in terms of the $1^{\text {st }}, 2^{\text {nd }}, 3^{\text {rd }}, 4^{\text {th }}$, and $5^{\text {th }}$ cycle slake durability indices, grain size distribution of laboratory slaked material (termed here as $\left.D_{R L}\right)$, and disintegration ratio $\left(D_{R}\right)$.

In the present study, slake durability indices were determined after each of five test cycles and the disintegration ratio was determined at different time periods during one-year exposure according to the abovementioned procedures. 

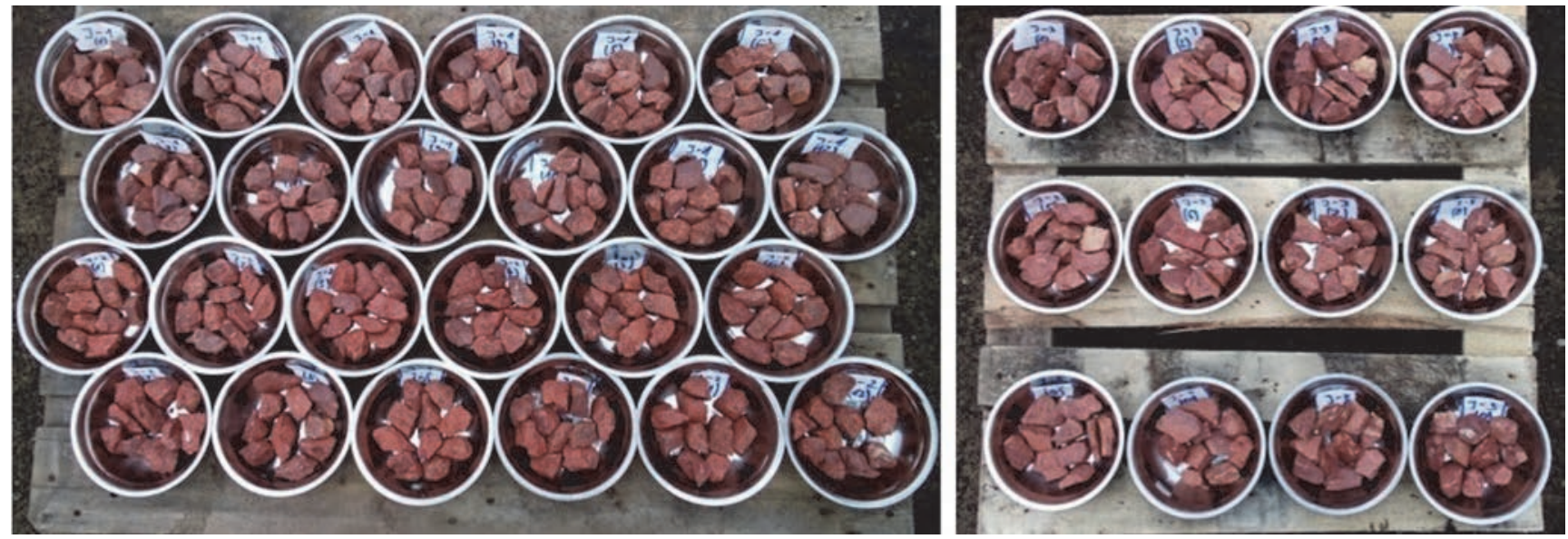

Figure 8. Samples exposed to natural climatic conditions

Table 4. Slake durability indices and disintegration ratios in natural and laboratory conditions

\begin{tabular}{|c|c|c|c|c|c|c|}
\hline Location & $\begin{array}{l}\text { Potter et al. } \\
\text { classification }\end{array}$ & Id2 $[\%] / D_{\text {RL2 }}$ & Id5 [\%]/D ${ }_{\mathrm{RL5}}$ & $\begin{array}{c}\mathrm{D}_{\mathrm{R}} \\
\text { (after } 2 \text { months) }\end{array}$ & $\begin{array}{c}D_{R} \\
\text { (after } 5 \text { months) }\end{array}$ & $\begin{array}{c}\mathrm{D}_{\mathrm{R}} \\
\text { (after } 12 \text { months) }\end{array}$ \\
\hline KM 22+850 & Silty shale & $98 / 0.98$ & $97 / 0.97$ & $0.98^{a}$ & $0.97^{\mathrm{a}}$ & $0.96^{a}$ \\
\hline KM 28+650 & Mud shale & $95 / 0.92$ & $91 / 0.88$ & $0.92^{b}$ & $0.91^{b}$ & $0.86^{b}$ \\
\hline KM 30+200 & Mud shale & $97 / 0.97$ & $92 / 0.89$ & $0.92^{c}$ & $0.82^{c}$ & $0.70^{c}$ \\
\hline
\end{tabular}

Test material was taken from three studied locations by excavating trial pits to the depths that were not influenced by weathering. Samples for determining the disintegration ratio were prepared according to ASTM D 4644 and placed in twelve metal pans representing twelve months, Figure 8 . Prior to exposure, samples were oven dried for 24 hours at $50^{\circ} \mathrm{C}$. This temperature was chosen according to suggestions given in Gautam and Shakoor [40].

\section{Disintegration test results}

Results of slake durability tests are shown in Table 4. Figure 9.a and 9.b shows samples prior to testing and after the second and fifth cycles. The slake durability index ranges between 95 $\%<\operatorname{ld}(2)<98 \%$. In order to classify the degree of disintegration after the first and second test cycles, Gamble [45] proposed a classification, which was modified by Erguler and Shakoor [43],
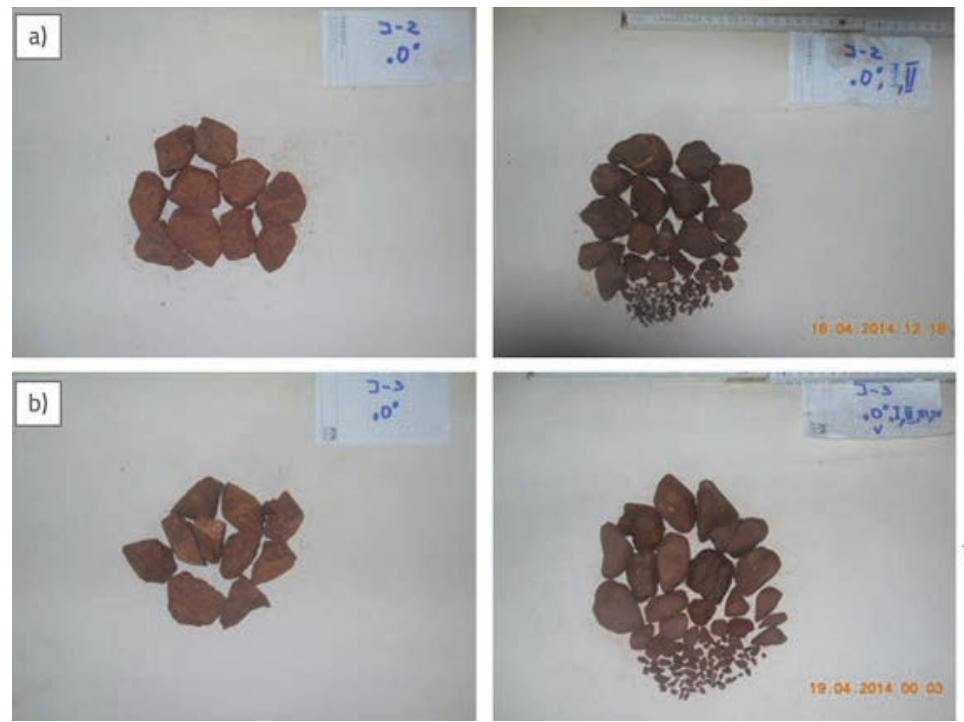

c)
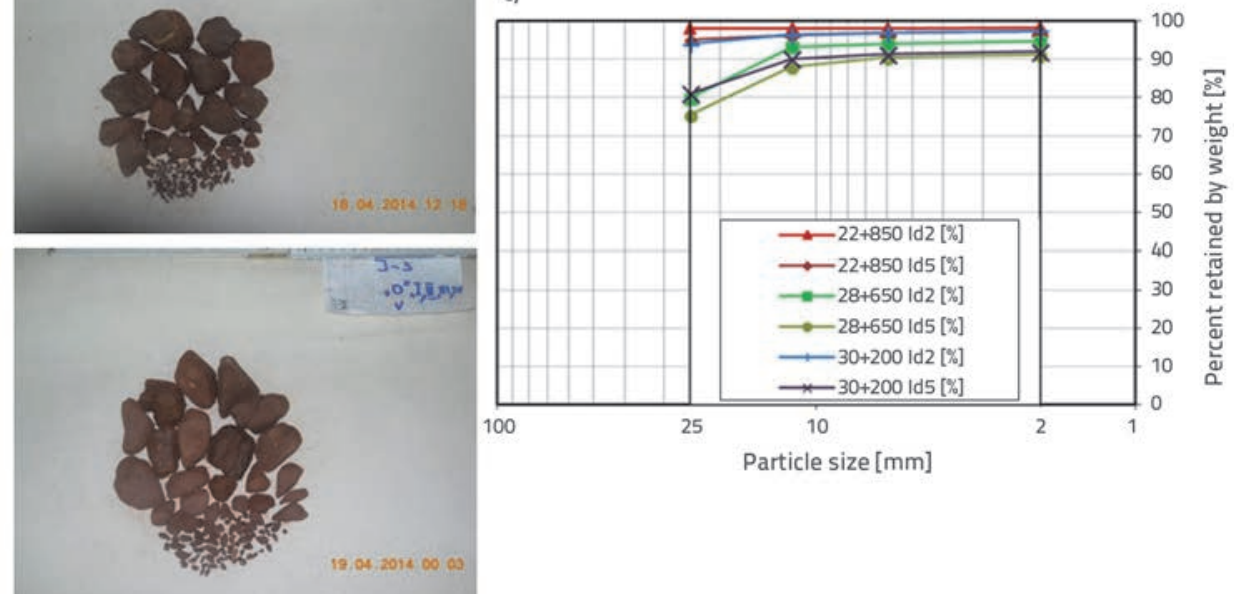

Figure 9. a) Sample from km 28+650 before test and after second cycle, b) Sample from km 30+200 before test and after fifth cycle, c) Grain size curves after second and fifth cycles 
Table 5. Slake durability classification system based on disintegration ratio [43]

\begin{tabular}{|c|c|c|}
\hline Durability classification & Second-cycle slake durability index (Id2 \%) & Disintegration ratio $\left(\mathbf{D}_{\mathbf{R L}}\right)$ \\
\hline Very high & $>98$ & $0.96-1.00$ \\
\hline High & $95-98$ & $0.92-0.95$ \\
\hline Medium high & $85-95$ & $0.79-0.91$ \\
\hline Medium & $60-85$ & $0.50-0.78$ \\
\hline Low & $30-60$ & $0.20-0.49$ \\
\hline Very low & $<30$ & $0.0-0.19$ \\
\hline
\end{tabular}

Table 5. According to this classification, Permian sediments belong to the group of sediments exhibiting high to very high resistance to disintegration. Material retained after testing consists of large and small fragments. Grain size curves of all samples after the second and fifth cycles are shown in Figure 9c. Determination of grain size curve after each slake durability cycle produces better comparison between laboratory samples and the samples exposed to natural climatic conditions. As shown in Table 4, $D_{\mathrm{RL}}$ value is similar to that of an appropriate Id index. Table 4 also shows disintegration ratio values determined after 2, 5, and 12 months for samples J-1(7), J-2(12) and J-3(2), (see Table 6).

Samples were placed on the roof of a private building and exposed to natural climatic conditions from April 2014 to April 2015 , i.e. during a one-year time period. The disintegration ratio was determined after 2, 5, 9, and 12 months of exposure on representative samples from each location. Due to transport difficulties sieving of all 36 samples was done after 12 months of exposure only. Samples for which $D_{R}$ coefficient was determined after $2,5,9$, and 12 months were carefully chosen after visual

Table 6. Disintegration ratio

\begin{tabular}{|c|c|c|c|c|c|c|c|c|c|c|c|}
\hline Location & Sample & $D_{R 2}$ & $\mathrm{D}_{\mathrm{R} 5}$ & $D_{R g}$ & $D_{\mathrm{R} 12}$ & Location & Sample & $D_{R 2}$ & $D_{R 5}$ & $D_{R g}$ & $D_{\mathrm{R} 12}$ \\
\hline \multirow{12}{*}{ KM 22+850 } & $J-1(1)$ & & 0.96 & 0.95 & 0.93 & \multirow{12}{*}{ KM 28+650 } & $J-2(1)$ & & & 0.86 & 0.84 \\
\hline & $J-1(2)$ & & & & 0.90 & & $J-2(2)$ & & & & 0.95 \\
\hline & $J-1(3)$ & & & & 0.95 & & $J-2(3)$ & & & & 0.84 \\
\hline & $J-1(4)$ & & & & 0.94 & & $J-2(4)$ & & & & 0.84 \\
\hline & $J-1(5)$ & & & & 0.97 & & $J-2(5)$ & & & & 0.97 \\
\hline & $J-1(6)$ & & & & 0.93 & & $J-2(6)$ & & & & 0.89 \\
\hline & $J-1(7)$ & 0.98 & 0.97 & 0.96 & 0.96 & & $J-2(7)$ & & & & 0.91 \\
\hline & $J-1(8)$ & & & & 0.97 & & $J-2(8)$ & & & & 0.95 \\
\hline & $J-1(9)$ & & & & 0.96 & & $J-2(9)$ & & 0.97 & 0.91 & 0.90 \\
\hline & $J-1(10)$ & & & & 0.96 & & $J-2(10)$ & & & & 0.89 \\
\hline & $J-1(11)$ & & & 0.96 & 0.92 & & $J-2(11)$ & & & & 0.91 \\
\hline & $J-1(12)$ & & & & 0.93 & & $J-2(12)$ & 0.92 & 0.91 & 0.88 & 0.86 \\
\hline \multirow{12}{*}{ KM 30+200 } & $J-3(1)$ & & & & 0.79 & & & & & & \\
\hline & $J-3(2)$ & 0.92 & 0.82 & 0.69 & 0.70 & & & & & & \\
\hline & $J-3(3)$ & & & & 0.78 & & & & & & \\
\hline & $J-3(4)$ & & & & 0.71 & & & & & & \\
\hline & $J-3(5)$ & & 0.82 & 0.69 & 0.66 & & & & & & \\
\hline & $J-3(6)$ & & & & 0.67 & & & & & & \\
\hline & $J-3(7)$ & & & & 0.68 & & & & & & \\
\hline & $J-3(8)$ & & & & 0.72 & & & & & & \\
\hline & $\mathrm{J}-3(9)$ & & & & 0.73 & & & & & & \\
\hline & $J-3(10)$ & & & 0.79 & 0.76 & & & & & & \\
\hline & $J-3(11)$ & & & & 0.83 & & & & & & \\
\hline & $J-3(12)$ & & & & 0.78 & & & & & & \\
\hline
\end{tabular}



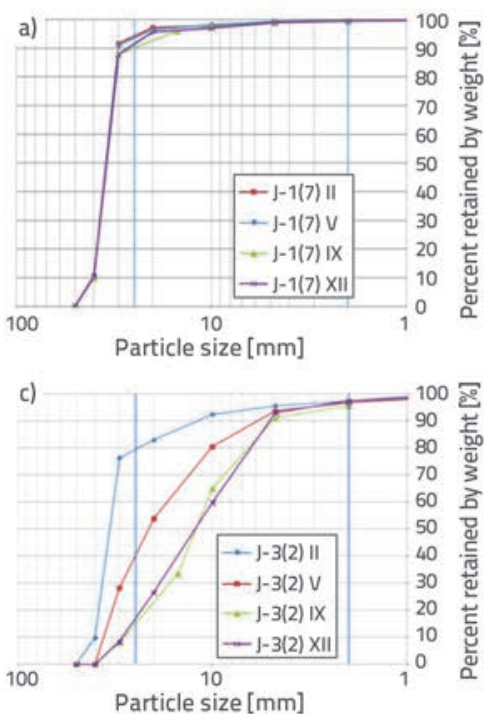

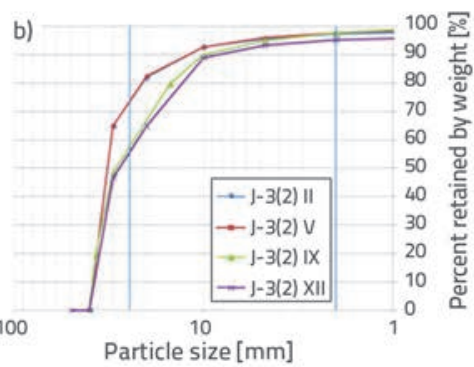

d)

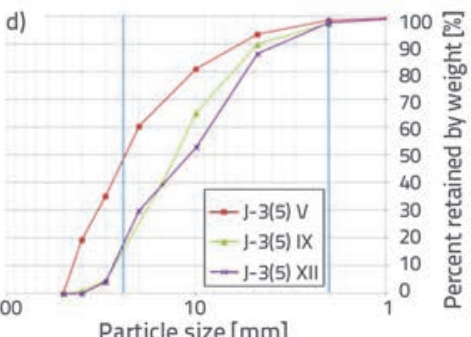

Particle size $[\mathrm{mm}]$

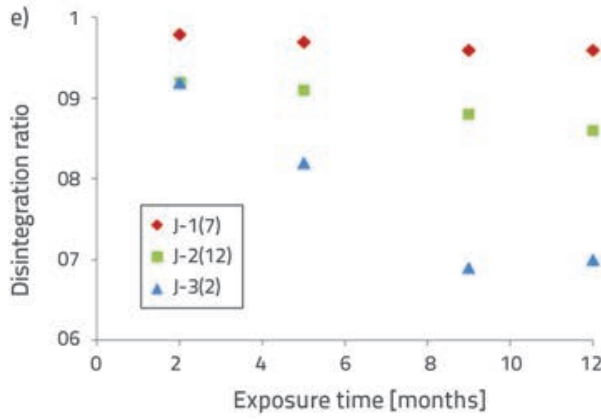

Figure 10. Grain size curves: a) J-1(7), b) J-2(12), c) J-3(2), d) J-3(5), e) disintegration ratio with exposure time

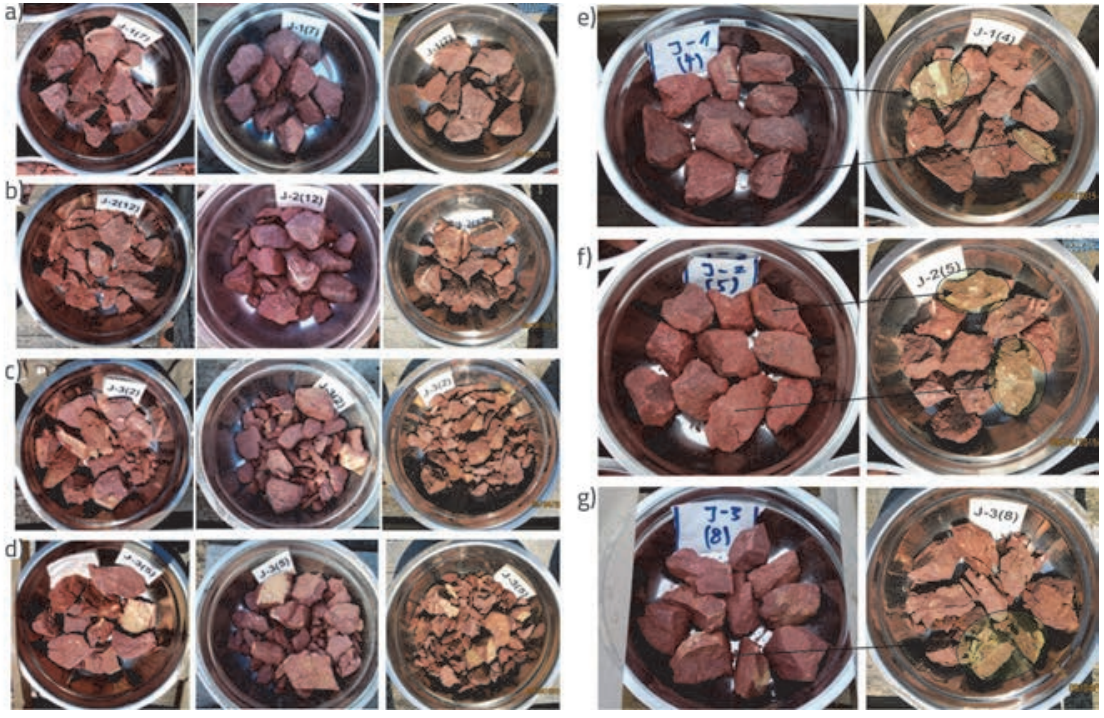

Figure 11. Samples after 2, 5, and 12 months a) J-1(7); b) J-2(12); c) J-3(2); d) J-3(5); and change in surface conditions for samples e) J-1(4); f) J-2(5); g) J-3(8)

inspection so as to obtain an average degree of disintegration of all samples from one location. After sieving, samples were reexposed to elements in order to monitor further disintegration. As shown in Table 6, samples from location at km 22+850 (designated J-1) are the least susceptible to disintegration, whereas samples from location at km 30+200 (designated J-3) exhibit the highest level of susceptibility to disintegration.

Grain size curves for samples J-1(7), J-2(12), J-3(2), and J-3(5) are shown in Figure 10.a to 10.d. It can be seen that the highest rate of disintegration is achieved during the first five month of exposure, whereas disintegration between 9 and 12 months of exposure is insignificant. The results show that the rock mass is moderately resistant to weathering (except in the case of samples from location 22+850). Disintegration ratios with exposure time for samples from three locations are shown in Figure 10.e.
Appearance of samples prior to and after exposure to atmospheric conditions is shown in Figure 11. Figure 11 shows that mechanical properties of Permian sediments are influenced by rock mass disintegration in two ways. At first, new cracks develop on intact pieces, pre-existing discontinuities become wider, and process of fragmentation is initiated. During further exposure, discontinuity surfaces are altered, and quality is reduced. Alteration of discontinuity surfaces cannot be obtained in shortterm laboratory tests. Prior to exposure the samples were slightly to moderately weathered, thus surface conditions were of good to fair quality. After one year of exposure, the quality of surface conditions was on an average reduced by one category. These changes also influenced the surface roughness. If all exposed samples are grouped into one pile of loose rock with behaviour similar to that shown by Hoek [46], the following conclusions can be made :

- Intact rock pieces are formed by several intersecting discontinuity sets of certain quality. Initially they have one GSI value.

- As a consequence of exposure, the new cracks develop and samples disintegrate into smaller fragments. Discontinuity surfaces are altered and quality is reduced. This leads to reduction in GSI value.

\section{Concept of strength reduction due to weathering}

As a consequence of disintegration, the GSI value reduces in both horizontal and vertical directions. Initial SCR coefficient rating, as well as the block volume, should be reduced on GSI chart, Figure 7. 
At some point of disintegration, alteration will progress into the interior of the rock mass, and thus the material constant $\left(m_{i}\right)$ and the uniaxial compressive strength $\left(\sigma_{c}\right)$ should be reduced. Disturbance factor is a consequence of stress relaxation and/ or blasting, and should not be changed due to weathering. The concept that is shown here accounts only for the reduction of GSI value of considered Hoek and Brown material.

In order to analyse the influence of GSI reduction on the stability of the cuttings, the slope stability analyses were performed using the software package Slide, assuming plane strain conditions. Lower bound values of initial shear strength parameters of GT III material (Table 3) were used in forward analyses. Since Permian sediments are a typical HB material, appropriate calculations were performed using the Bishop's simplified method. Back analyses were performed on predefined failure surfaces where the state of failure was reached by reducing initial GSI value to the value for which FoS equals unity. Morgenstern-Price method, with an assumption of half-sine interslice force function $f(x)$, was used to perform back analyses since the failure surface observed at km 28+650 has a composite shape.

With regard to pore pressures, the only information available is that the phreatic water surface is well below the observed failures, thus an assumption is made of cutting material in dry conditions. Values of the factors of safety just after excavation for cuttings at KM 22+850, KM 28+650, and KM 30+200 are

a)
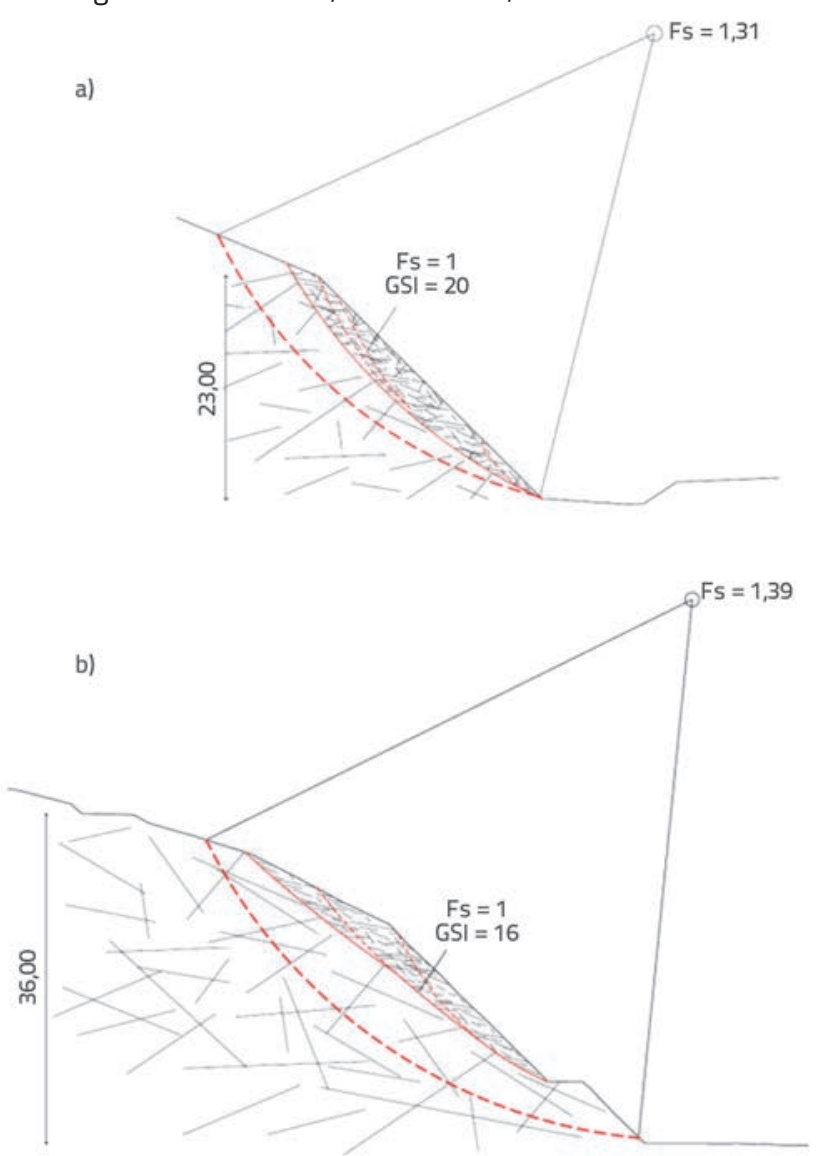

1.31, 1.39, and 1.68, respectively. The cutting at KM 22+850 exhibits the lowest FoS and an instability occurred three months following the exposure. An average critical GSI value at the time of failure is equal to 20 . The global failure at $\mathrm{km}$ $28+650$ occurred six months after excavation with an average GSI value of 16 . The lowest slope at $\mathrm{km} 30+200$ exhibits the lowest average GSI value equal to 15 at the time of failure. In other words, the slope with the lowest initial FoS will be the first to suffer from instability at the moment of reaching the highest critical GSI value. In order to become unstable, a lower cutting needs to disintegrate to a higher extent and reach a lower critical GSI value. Variation of FoS with exposure time is shown in Figure 12.d.

Local failures can sometimes be observed, producing lower GSI values, due to material heterogeneity and possible existence of weaker zones at the face of the cuttings.

The GSI value reduces by one third during the first three months of exposure, whereas the initial GSI value reduces up to $50 \%$ after one year, Figure 13. The critical GSI values for cuttings at KM 29+400, KM 29+900 and KM 30+050 are shown in Figure 12 along with GSI values obtained from three studied locations. These cuttings are all $12 \mathrm{~m}$ in height, with the slope inclination of $1: 1$. The state of failure is reached after 12,13 , and 15 months, respectively (Table 1 ). It can therefore be concluded that the largest decrease in GSI value should be expected during the first six months after exposure. The reduction in GSI value is

c)
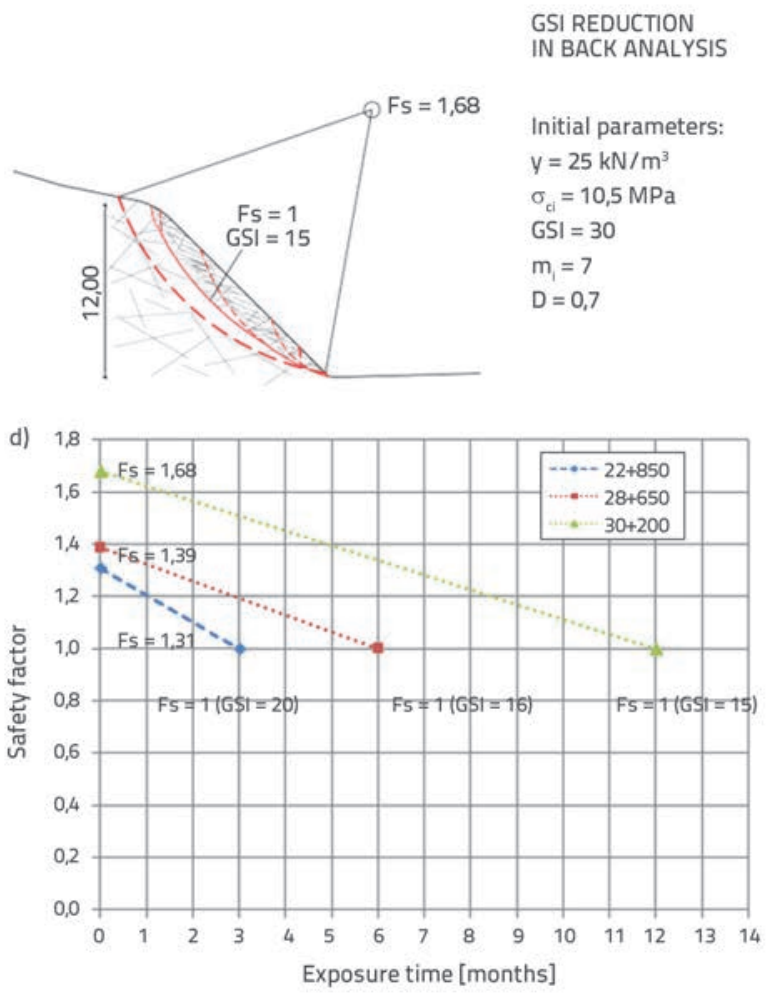

Figure 12. Slope stability analyses (not to scale): a) KM 22+850, b) KM 28+650, c) KM 30+200, d) safety factor with exposure time 

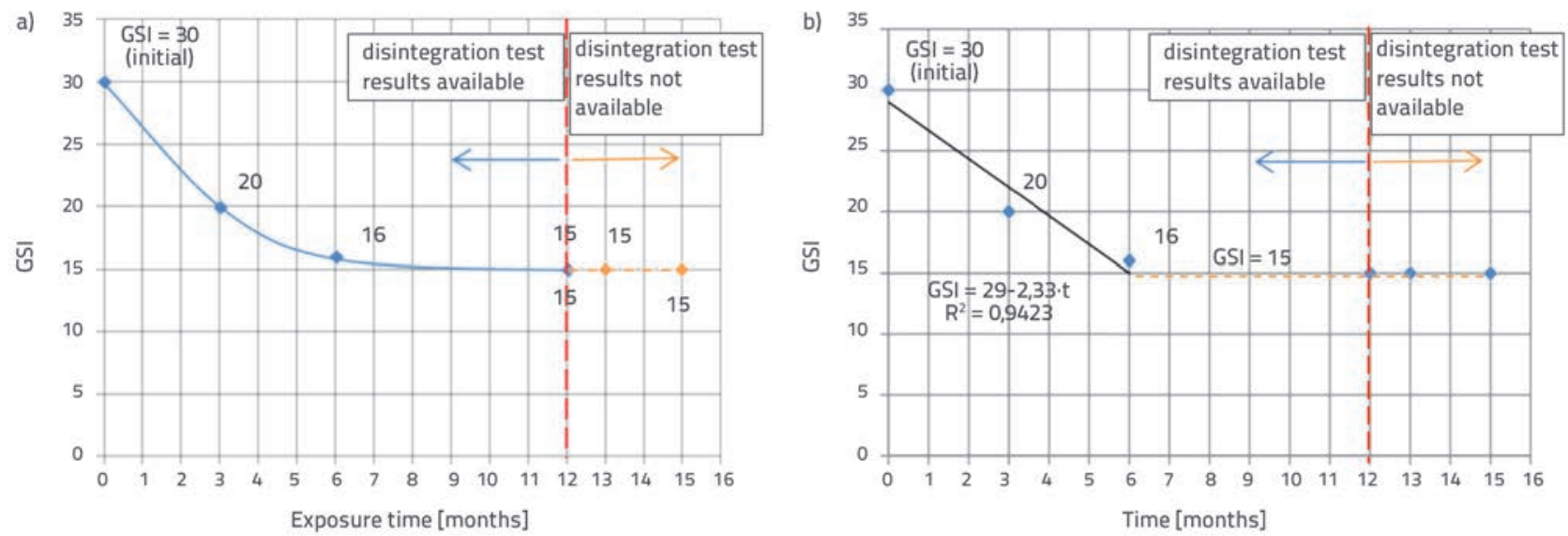

Figure 13. a) GSI value with exposure time for 1:1 slope geometry; b) GSI reduction as a bilinear function

expected to be negligible between six and twelve months after exposure, whereas GSI value tends to an asymptotic value of 15. These findings are in general agreement with the rate of disintegration as represented by grain size distribution curves, Figure 10.

The GSI reduction can be approximated by bilinear function with a relatively high accuracy, Figure 13b. It is suggested that the conservative GSI value of 15 be used for slope stability analyses if slope stays unprotected during the periods of more than 6 months. Bilinear equation can be expressed as :

$G S I=29-2,33 \cdot t($ for $t<6), \quad G S I=15($ for $6<t<15)$

where $t$ is the exposure time in months.

\section{Conclusions}

A possible cause of a large number of delayed slope failures in red Permian sediments encountered during construction of a part of the E80 Highway Project is explained in this study. It is suspected that the weathering process plays a crucial role in the reduction of shear strength of a typical HB material. Even though the second cycle slake durability indices show that braided river deposits are highly resistant to disintegration, exposure of specially prepared samples to natural climatic conditions shows that samples have medium to medium-high resistance to disintegration. After one year of exposure, the quality of surface conditions is reduced, on an average, by one category. This is accounted for by reducing the GSI index. A bilinear function explaining the decrease in GSI value with exposure time is proposed. These findings can be used to perform analyses on cuttings of different height and inclination in Permian and similar sediments. This is of prime importance if slopes are exposed to atmospheric conditions for a longer period of time. The proposed methodology has several limitations such as :

- It is valid for a considered time period only.

- As discussed by Gautam and Shakoor [44], the moment of exposure of specimens to natural climatic conditions (e.g. winter or summer months) influences the number of freeze-thaw, wetting-drying, and heating-cooling cycles. Unfortunately, slight differences in disintegration rate are possible in this study, as authors were unable to collect samples such as to match their exposure month to the month of cutting excavation. However, disintegration rate as shown by grain size distribution curves shows good agreement with observed disintegration rate of slope material.

- Disintegration zone could be thicker than proposed, whereby GSI value does not change uniformly with depth. The proposed concept assumes average GSI values along failure surface.

- It does not account for reduction of intact parameters $\sigma_{c i}$ and $m_{i}$

\section{REFERENCES}

[1] Bjerrum, L.: Progressive failure in slopes in overconsolidated plastic clay and clay shales. Terzaghi Lecture, J Soil Mech Found Div, ASCE 93 (1967) 5, pp. 3-49.

[2] Botts, M.E.: Effects of Slaking on the Strength of Clay Shales: A Critical State Approach, Proceedings of the $2^{\text {nd }}$ International Symposium on the Geotechnics of Hard Soils / Soft Rocks, Vol. 1, Naples, Italy, 1998.

[3] Morgenstern, N.R., Eigenbrod, K.D.: Classification of argillaceous soils and rocks, Proc. ASCE J Geotech Eng Div. 190, GT10 (1974) pp. 1137-1156.

[4] Miščevic, P., Vlastelica, G.: Impact of weathering on slope stability in soft rock mass, J Rock Mech Geotech Eng, 6 (2014) 3, pp. 240250. 
[5] Vlastelica, G., Miščević, P., Pavić, N.: Testing the shear strength of soft rock at different stages of laboratory simulated weathering, GRAĐEVINAR, 68 (2016) 12, pp. 955-966, https://doi. org/10.14256/JCE.1878.2016

[6] Badger, C.W., Cummings, A.D., Whitmore, R.L.: The disintegration of shale, Journal of the Institute of Fuel, 29 (1956), pp. 417-423.

[7] Nakano, R.: On the weathering and change of Tertiary mudstone related to landslide, Soil and Foundations, 7 (1967), pp. 11-14.

[8] Taylor, R.K., Spears, D.H.: The breakdown of Coal Measures rocks, Int J Rock Mech Min Sci, 7 (1970), pp. 481-50.

[9] Bell, F.G.: Engineering geology Second ed. Elsevier Ltd., Chapter 3, pp. 77-149, 2007.

[10] Olivier, H.J.: A new engineering-geological rock durability classification, Eng Geol., 14 (1979). pp. 255-279.

[11] Van Der Merwe, D.H.: The prediction of heave from the plasticity index and percentage clay fraction of soils. The Civil Engineer in South Africa, Institute of Civil Engineers. S. Africa., 6 (1964), pp. 103-116.

[12] O'Neill, M.W., Poormoayed, A.M.: Methodology for foundations on expansive clays, J Soil Mech Found Div, ASCE 106 GTI, 2 (1980), pp. 1345-1367.

[13] Grubić, A., Đoković, I., Marović, M., Toljić, M.: Complex geological study of Resava-Mlava coal basins, Coal mine "Resavica" technical documentation, Resavica (in Serbian), 1989-1992.

[14] Berisavljević, Z.: Weathering characteristics of heterogeneous Permian-age siltstone and mudstone sediments from Serbia, Proceedings of the $33^{\text {rd }}$ Symposium of the International Society for Rock mechanics EUROCK2017 Ostrava, Czech Republic, 2017.

[15] Vujisić, T., Navala, M., Kalenić, M., Krstić, B., Maslarević, Lj. Marković, B., Buković, J.: Explanatory booklet for the basic geological map of SFR Yugoslavia-Sheet Bela Palanka 1:100 000, Federal geological survey, Belgrade (in Serbian), 1980.

[16] Potter, P.E., Maynard, J.B., Pryor, W.A.: Sedimentology of Shale, Springer Verlag, New York, 1980.

[17] Hoek, E.: Strength of rock and rock masses, News J ISRM, 2 (1994) 2, pp. 4-16.

[18] Hoek, E., Kaiser, P.K., Bawden, W.F.: Support of underground excavations in hard rock, Balkema, Rotterdam, 1995.

[19] Sonmez, H., Ulusay, R.: Modifications to the geological strength index (GSI) and their applicability to the stability of slopes, Int J Rock Mech Min Sci, 36 (1999), pp. 743-760.

[20] Cai, M., Kaiser, P.K., Uno, H., Tasaka, Y., Minami, M.: Estimation of rock mass deformation modulus and strength of jointed hard rock masses using the GSI system, Int J Rock Mech Min Sci, 41 (2004), pp. 3-19.

[21] Russo, G.: A new rational method for calculating the GSI. Tunnel Underground Space Technol, 24 (2009), pp. 103-111.

[22] Hoek, E., Carter, T.G., Diederichs, M.S.: Quantification of the Geological Strength Index Chart, 47 ${ }^{\text {th }}$ US Rock Mechanics / Geomechanics Symposium, San Francisco, 2013.

[23] Bieniawski, Z.T.: Engineering rock mass classifications, John Wiley \& Sons, New York, 1989.

[24] Bieniawski, Z.T.: Tunnel design by rock mass classifications, US Army Corps of Engineers, GL-79-19, 1990.

[25] Dearman, W.R.: Engineering geological mapping Butterworth Heinemann Ltd., Oxford, 1991.
[26] Marinos, P., Hoek, E.: Estimating the geotechnical properties of heterogeneous rock masses such as flysch, Bull Eng Geol Environ, 60 (2001), pp. 85-92.

[27] Marinos, V.: New proposed GSI classification charts for weak or complex rock masses, Bull Geol Soc Greece, XLIII (2010) 3, pp. $1248-1258$.

[28] ISRM SM for Determining the Uniaxial Compressive Strength and Deformability of Rock Materials, Part 1 - SM for Determination of the Uniaxial Compressive Strength of Rock Materials, 1979.

[29] Wood, L.E., Deo, P.: A suggested system for classifying shale materials for embankments, Bull Assoc Eng Geol., 12 (1975) 1, pp. 39-55.

[30] Deo, P.: Shales as Embankment Materials, PhD Thesis, Purdue University, 1972

[31] Franklin, J.A., Chandra, R.: The slake-durability test, Int J Rock Mech Min Sci, 9 (1972), pp. 325-341.

[32] ASTM Standard Test Method for Slake Durability of Shales and Similar Weak Rocks, ASTM designation D 4644-08, 2008.

[33] Taylor, R.K.: Coal measures mudrocks: composition, classification and weathering processes, Q J Eng Geol., 21 (1988) 1, pp. 85-99.

[34] Moon, V.G., Beattie, A.G.: Textural and microstructural influences on the durability of Waikato coal measures mudrocks, Q J Eng Geol., 28 (1995) 3, pp. 303-312.

[35] Bell, F.G., Cripps, J.C., Culshaw, M.G.: Groundwater in Engineering Geology, Geological Society, London, Engineering Geology Special Publications, 3 (1986), pp. 1-23.

[36] Crosta, G.: Slake durability vs ultrasonic treatment for rock durability determinations Int J Rock Mech Min Sci, 35 (1998) 6, pp. 815-824.

[37] Miščevic, P., Vlastelica, G.: Durability characterization of marls from the region of Dalmatia, Croatia. Geotech Geol Eng, 29 (2011), pp. 771-781.

[38] Cano, M., Tomas, R.: An approach for characterising the weathering behavior of Flysch slopes applied to the carbonatic Flysch of Alicante (Spain), Bull Eng Geol Environ (2014), doi:10.1007/ s10064-014-0632-6

[39] Bryson, L.S., Gomez-Gutierez, I.C., Hopkins, T.C.: Development of a new durability index for compacted shale Eng Geol., 139-140 (2012), pp. 66-75.

[40] Gautam, P., Shakoor, A.: Slaking behavior of clay-bearing rocks during a one-year exposure to natural climatic conditions, Eng Geol., 166 (2013), pp. 17-25.

[41] Santi, P.: Field methods for characterizing weak rock for engineering, Environ Eng Geosci, 12 (2006) 1, pp. 1-11.

[42] Santi, P., Higgins, J.: Methods for predicting shale durability in the field, Geotech Test J, 21 (1998) 3, pp. 195-202.

[43] Erguler, Z.A., Shakoor, A.: Quantification of fragment size distribution of clay bearing rocks after slake durability testing, Environ Eng Geosci, 15 (2009) 2, pp. 81-89.

[44] Gautam, T.P., Shakoor. A.: Comparing the Slaking of Clay-Bearing Rocks Under Laboratory Conditions to Slaking Under Natural Climatic Conditions, Rock Mech Rock Eng, 49 (2016), pp. 19-31.

[45] Gamble, J.C.: Durability-plasticity classification of shales and other argillaceous rocks, PhD Thesis, University of Illinois, 1971.

[46] Hoek, E.: Strength of jointed rock masses, $23^{\text {rd }}$ Rankine Lecture, Geotechnique, 33 (1983) 3, pp. 187-223. 